\title{
IMPLEMENTASI GYROSCOPE-ARDUINO PADA KENDALI KESEIMBANGAN
}

\author{
Eddy Nurraharjo ${ }^{1}$, Zuly Budiarso ${ }^{2}$ \\ ${ }^{1,2}$ Program Studi Teknik Informatika, Fakultas Teknologi Informasi, Universitas Stikubank \\ e-mail: ${ }^{1}$ eddynurraharjo@edu.unisbank.ac.id, 22zulybudiarso@edu.unisbank.ac.id
}

\begin{abstract}
Abstrak
Gyroscope merupakan salah satu fitur yang dimiliki oleh modul GY-521, disamping kemampuan accelerometernya. Fokus pengamatan pada penelitian ini adalah upaya untuk membuat konsep antarmuka terhadap gyroscope-accelerometer dengan mengintegrasikannya bersamaan dengan modul Arduino UNO R3. .

Arduino menjadi inti dalam pemrosesan sinyal yang dihasilkan dari modul GY-521, dan diolah dengan formulasi sederhana menggunakan konsep segitiga siku-siku, unutk kemudian dihailkan data keluaran dengan simulasi menggunakan motor servo, sebagai indikasi pitch dan roll.

Hasil penelitian ini adalah model komunikasi interaksi hasil perancangan antarmuka sistem yang diamati, dan mampu memberikan hasil pendekatan terhadap perubahan sudut dan respon motor servo terkendali dengan formulasi segitiga siku-siku dan batasan sudut 90 derajat sudut gerakan. Simulasi diberikan pada range sudut sebesar -90 hingga +90 derajat. Library yang terlibat dalah Wire.h, SPI.h dan Servo.h yang diperoleh dari internet.
\end{abstract}

Kata kunci: arduino, mikrokontroler, gyroscope, accelerometer

\section{PENDAHULUAN}

Gyroscope merupakan salah satu fitur yang dimiliki oleh modul GY-521, disamping kemampuan accelerometernya. Fokus pengamatan pada penelitian ini adalah upaya untuk membuat konsep antarmuka terhadap gyroscope-accelerometer dengan mengintegrasikannya bersamaan dengan modul Arduino UNO R3.

Implementasi gyroscope-accelerometer ini yang terpenting adalah pada pengendalian sistem pada sebuah perangkat terbang, seperti pesawat, yang dalam pemodean mininya berupa drone. Hal ini telah menjadi sebuah kebutuhan pada sistem kendali perangkat terbang ini, namun mereka para produsen lebih menyukai perangkat yang embeded pada produksi mereka, sehingga dalam perancangan maupun pengembangan serta perbaikannya akan menjadi kendala terhadap sistem mereka. Beberapa modifikator telah berupaya unutk melakukannya secara manual dan otodidak, sehingga muncullah ide untuk menggabungkan kemampuan modul GY-521 dengan modul Arduino UNO R3 yang hingga saat ini telah menjadi tren pengenalan maupun pengembangan konsep sistem kendali maupun robotika tingkat dasar hingga menengah.

Kemudahan dalam perancangan, perakitan dan pemodelannya menjadikan sebagai salah satu faktor utama dalam pengamatan penelitian ini. Bebrapa kode program bayak ditemukan dari internet dan melakuka beberapa modifikasi untuk kemudian dicari solusi pendekatan terbaik terhadap hasil yang ingin dicapai, yaitu perubahan nilai gyroscope dan accelerometer.

Sistem kendali yang menantang ini akan menjadi bahan pengamtan pada penelitian ini dengan harapan dapat memperoleh pengembangan model sistem kendali dengan menggunakan basis gyroscope-accelerometer. Model akan menggerakkan motor untuk merespon perubahan nilai gyro dan accelrometernya.

\section{PERUMUSAN MASALAH}

Model yang akan dibangun dalam sistem ini adalah respon sistem terhadap perubahan data keluaran berupa pergerakan motor servo, yang akan mewakili perubahan data pada nilai gyrsocope dan accelerometernya. Beberapa teknik dan formulasi sederhana hingga kompleks telah banyak 
tersebar di dunia maya atau internet, akan tetapi bagaimana konsep interfacing, dan kode program yang cocok dengan modul GY-521 ini akan rancang untuk memperoleh respon terbaik.

\section{BATASAN MASALAH}

Adapun batasan masalah dalam kesempatan penelitian ini adalah:

a. Rancang bangun berbasis sistem kendali dengan ini menggunakan mikrokontroler ATMEL ATMEGA238P-PU yang terangkai pada sebuah modul arduino UNO R3.

b. Pengamatan dan pengujian sistem kendali fokus pada sensor accelerometer-gyro dengan menggunakan modul GY-521, dengan sistem kendali penggerak berbasis motor servo.

\section{TUJUAN DAN MAFAAT PENELITIAN}

Adapun tujuan dalam penelitian pada kesempatan kali ini adalah:

a. Mengetahui prinsip dasar pemrograman funsi formulasi segitiga siku-siku

b. Mengetahui teknik interfacing komunikasi port antara modul GY-521 dan Arduino UNO R3

Manfaat yang ingin dicapai dalam penelitian ini adalah:

a. Memberikan wawasan pemrograman modul sistem kendali berbasis formula

b. Memberikan wawasan perancangan modul sistem kendali berbasis gyrsocope-accelerometer

c. Memberikan wawasan teknik interfacing dengan mikrokontroler tipe Arduino dalam berbagai variasi modulnya

\section{METODE PENELITIAN}

Metode yang akan digunakan dalam penelitian ini terdiri dari langkah-langkah sebagai berikut :

a. Studi Literatur

Untuk memperoleh dasar teori berkaitan dengan pemodelan matematis, pemrograman selfbalancing mikrokontroler, pemrograman interfacing, sistem kendali terpadu, baik berasal dari jurnal, buku maupun informasi baku lainnya yang bersumber dari situs-situs di internet, berkaitan dengan perancangan dan pemrograman perangkat sistem kendali berbasis accelerometer berbasis Arduino.

b. Pemrograman Aplikasi

Pemrograman aplikasi ini dimaksudkan untuk menguji sebuah teknik self-responsive serta mengeksplorasi teknik interfacing dan mengimplementasikannya teknik/metode tersebut dalam sebuah aplikasi sistem kendali berbasis Arduino UNO R3, dengan simulasi penggerak menggunakan motor servo.

\section{HASIL DAN PEMBAHASAN}

Gyroscope merupakan sensor yang akan mengukur kecepatan sudut dalam $\alpha, \beta$, dan $\gamma$. Gyroscope sering digunakan untuk membantu penstabil dan memperbaiki perubahan arah dan pengarahan. Walaupun tidak seperti accelerometer, gyroscope tidak memiliki nilia referensi yang pasti, dan hanya akan memngukur perubahannya saja. Untuk melakukan pengaturan gyroscope sesuai dengan yang diinginkan, maka gambaran nilai rata-rata perubahan sudut maksimumnya (dalam derajat per detik) sangat diperlukan. Misal untuk menggerakkan kendali jarak jauh untuk bisa berotasi kurang dari satu putaran perdetik, maka bisa dinyatakan pula dengan 360 derajat per detik. Untuk menghubungkan dengan mikrokontroler 10 bit, maka nilai 360 derajat/detik pada gyro, akan memiliki akurasi $360 / 1024=0,35$ derajat/detik, sedangkan jika diinginkan 1500 derajat/detik akan menghasilkan akurasi 1500/1024 =1,46 derajat/detik. Oleh karena itu jika diinginkan 1500 derajt/detik gyro, akan tetapi hanya diperlukan 360 derajat/detik gyro, maka akan diperoleh 245 pembacaan sebagai kebalikan dari 1024. 


\section{Blok Diagram Sistem}

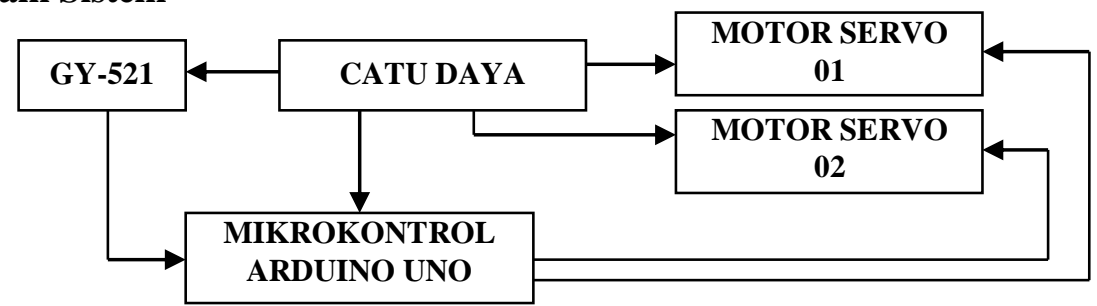

Gambar 1. Blok Diagram Sistem

Catudaya. Sumber tegangan dan arus yang digunakan untuk memberikan daya kepada setiap blok elemen bagian sistem kendali, yang bersumber dari sebuah baterai 8-16 volt.

Motor Servo. Sistem penggerak berbasis servo digunakan untuk memberikan simulasi terhadap efek dari sensor accelerometer dan gyroscope. Motor servo 01 sebagai simulasi sumbu arah $\mathrm{x}$ dan motor servo 02 sebagai simulasi sumbu arah $\mathrm{y}$.

Arduino. Sistem kendali utama dengan menggunakan Arduino UNO R3 dengan kekuatan inti sistem adalah mikrokontroler Atmega32.

GY-521. Sensor data masukan terhadap mikrokontroler dilakukan untuk mengukur nilai sumbu $\mathrm{x}$ dan nilai sumbu y, yang diperoleh dari modul accelerometer dan gyroscope. Perolehan data ini akan menentukan perilaku motor servo dengan memberikan perubahan gerakan secara signinfikan.

\section{Diagram Flowchart Sistem}

Program dimulai dari inisialisasi terhadap pengenalan perangkat masukan dan keluaran serta sejumlah variabel yang dibutuhkan, variabel akan mencoba menangkap perubahan terhadap besaran sudut dari sensor untuk kemudian diolah dengan menggunakan formulasi matematis geometri segitiga, nilai hasil perhitungan segitiga ini akan digunakan untuk memberikan besaran respon terhadap perubahan gerakan motor servo. Perubahan ini akan dideteksi secara real time.

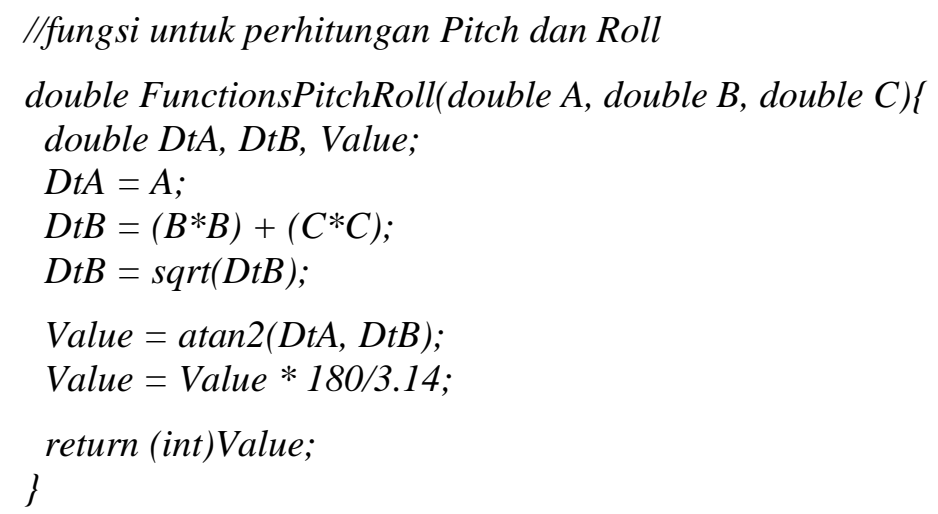

Fungsi untuk perhitungan pitch dan roll berdasarkan rumus segitiga siku-siku, dimisalkan satu sisinya adalah B dan sisi siku yang lain adalah $\mathrm{C}$, maka sisi miringnya meliputi formula fungsi akar kuadrat dari B dan $\mathrm{C}$, sedangkan untuk memperhitungkan besaran sudut antara sisi miring tersebut dengan sisi lainnya adalah arc tan diantara keduanya, kemudian nilai tersebut dikalikan dengan 180 derajat dan dilanjutkan dengan membaginya dengan nilai pi $(\pi)$. Besaran hasil dari perhitungan dikategorikan dalam tipe data integer. 


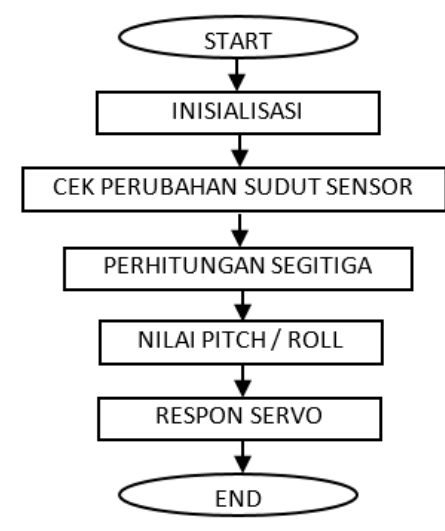

Gambar 2. Flowchart Sistem

Adapun hasil implementasi dapat ditampilkan dalam mode serial monitor berupa nilai terukur, dan capture tampilan visual pergerakan motor servo untuk pergerakan pitch and roll dapat diamati pada format tabel di bawah ini, dengan memberikan pendekatan nilai masukan berupa nilai sudut dalam derajat.

\section{KESIMPULAN}

Adapun beberapa kesimpulan yang berhasil diperoleh dalam penelitian ini diantaranya adalah sebagai berikut :

a. Hasil implementasi melibatkan beberapa library utama yaitu servo.h, wire.h, dan SPI.h, yang masing-masing digunakan untuk penggerak motor servo, komunikasi antarmuka dengan modul accelerometer dan gyroscope, dan library komunikasi data serial, mampu memberikan hasil signifikan terhadap nilai formulasi matematis sederhana yaitu segitiga siku-siku dan perhitungan besaran sudut, perubahan gyroscope dan accelerometer

b. Modul GY-521 dapat digunakan dengan melalui proses kalibrasi modul, inisialisasi MPU 6050, dan pertimbangan berkaitan dengan hasil yang diinginkan dalam implementasi fitur accelerometer dan gyroscope.

\section{DAFTAR PUSTAKA}

[1] Ardi Winoto, 2008, "Mikrokontroler AVR ATmega8/32/16/8535 dan Pemrogramannya dengan Bahasa C pada WinAVR", Penerbit Informatika, Bandung

[2] Endra Pitowarno, 2005, "Mikroprosesor \& Interfacing", Penerbit Andi, Yogyakarta

[3] Maik Schmidt, 2011, "Arduino - A Quick Start Guide Quick Start Guide", Pragmatic Programmers, LLC, USA

[4] Muhammad Riyadi, Wahyudi, Iwan Setiawan, 2010, Pendeteksi Posisi Menggunakan Sensor Accelerometer MMA7260Q Berbasis Mikrokontroler Atmega 32, Jurnal Transmisi, UNDIP Semarang

[5] Ruslan Gani, Wahyudi, Iwan Setiawan, 2013, Perancangan Sesnsor Gyroscope dan Accelerometer Untuk Menentukan Sudut dan Jarak, Makalah Seminar Tugas Akhir, UNDIP Semarang

[6] Yuga Aditya Pramana, Implementasi Sensor Accelerometer, Gyroscope Dan Magnetometer Berbasis Mikrokontroler Untuk Menampilkan Posisi Benda Menggunakan Inertial Navigation System (INS), UNIKOM 